\title{
IMPLEMENTATION OF THE SCHISTOSOMIASIS CONTROL TEAM (PEDA' TEAM) IN BADA HIGHLAND, CENTRAL SULAWESI PROVINCE, INDONESIA
}

\author{
Anis Nur Widayati ${ }^{1 *}$, Muhamad Faozan ${ }^{1}$, Junus Widjaja ${ }^{1}$, Ahmad Erlan ${ }^{1}$, Malonda \\ Maksud $^{1}$ and Resmiwaty ${ }^{2}$ \\ ${ }^{I}$ National Institute of Health Research and Development (NIHRD) Unit Donggala, Indonesia \\ ${ }^{2}$ Faculty of Social and Political Sciences, Universitas Tadulako, Palu, Indonesia
}

\begin{abstract}
Background. Schistosomiasis has been a community health problem in endemic areas. In Indonesia, it is caused by trematode Schistosoma japonicum, with snail Oncomelania hupensis lindoensis as its intermediate host. This disease is only found in three endemic areas in Central Sulawesi Province: Napu and Bada highlands, Poso Regency, and Lindu highland in Sigi Regency. Various schistosomiasis control efforts were accomplished for more than the last twenty years. However, the schistosomiasis prevalence in Indonesia still fluctuates. The study aimed to determine the effectiveness of the Peda' team in the research area. Method. One strategy of schistosomiasis control by community empowerment, namely the Bada Model, was implemented in Bada highland, Poso Regency, Central Sulawesi Province, from May to November 2019. One of the model's elements is the formation of the schistosomiasis control village team (namely Peda' Team), which was trained about schistosomiasis control. After the training, they were assigned several duties, including schistosomiasis socialization to the village community, stool sample collection, snail habitat control, snail and rats survey, and assisting the mass drug administration. The evaluation was conducted in stool sample coverage and the snail habitat area. Results. The results showed an increase in stool sample collection coverage in the community, becoming more than $80 \%$ in almost all endemic villages. We found the decrease from 26 become three focus areas because of the active effort to control the schistosomiasis intermediate snail focus area. Based on the results can be concluded that the Peda team formation can support schistosomiasis control more useful in the research area
\end{abstract}

Keywords: Schistosomiasis, Bada Model, Community Empowerment

\section{Introduction}

Schistosomiasis is a tropical disease, which has been still a neglected health problem in Indonesia, especially in the Bada, Napu, and Lindu highlands, across 28 villages of Poso and Sigi Regencies, Sulawesi Tengah Province. It was first discovered in the Lindu Plateau in 1937, in the Napu Plateau in 1974, and in the Bada Highlands in 2008. The blood worm Schistosoma japonicum within snail Oncomelania hupensis lindoensis as its intermediate host was responsible for the disease. It attacks humans and harms the economy and public health. On a chronic level, it results in a decreased ability of people to work and, in some cases, results in death (Garjito et al., 2008; Sudomo \& dan Pretty, 2007)

As of 2018, the prevalence of schistosomiasis in Indonesia was still fluctuating. Its high prevalence in livestock, the less adequate handling of focus (intermediate snail habitat), and the inadequate community empowerment and cross-sectoral role at the village level as the vanguard in prevention, early detection, and control of schistosomiasis led to that fluctuation. 


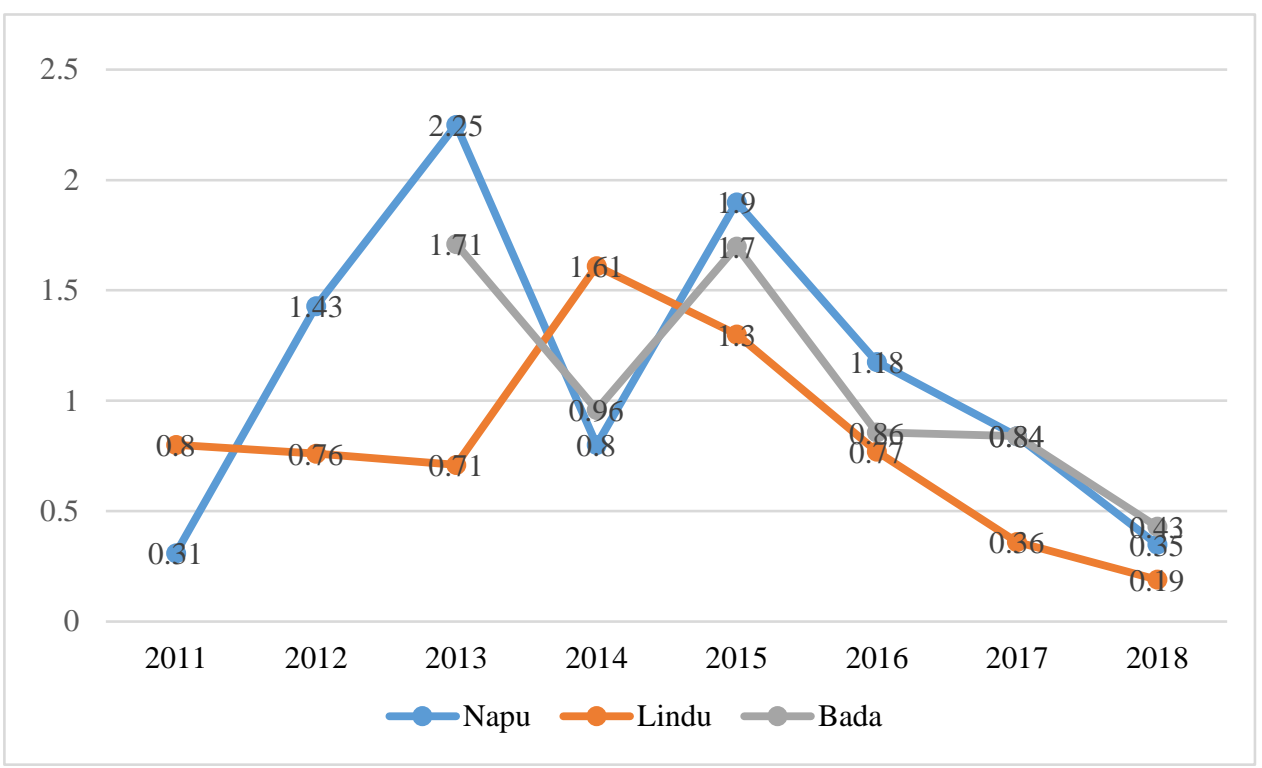

Figure 1. Schistosomiasis Prevalence in Indonesia 2011-2018 (Sulawesi Tengah Provincial Health Office, 2019)

Schistosomiasis control has been carried out by the Sulawesi Tengah Provincial Health Office in collaboration with the Poso District Health Office and the Lengkeka Schistosomiasis Laboratory, without massively involving the community. The community, therefore, needs to be involved and empowered in schistosomiasis control to achieve elimination by 2024 .

Schistosomiasis control in Indonesia has faced many difficulties even though the endemic areas are very limited. Diminishing funding after the termination of the CSIADC project in 2005 resulted in staff reductions in both schistosomiasis control stations, and inconsistent surveillance and control. A level of very low prevalence has been achieved but more agility is needed to eliminate the disease. The full participation of the health sector, as well as intersectoral collaboration, are key factors in the struggle to eliminate schistosomiasis in Indonesia. Unfortunately, a lack of coordination and collaboration between the Ministry of Health and others departments occurred repeatedly, possibly leading to increased re-infection rates and control failure. Increasing awareness among the local community is essential to support the environmental management programme since this approach has proven to be the best schistosomiasis control tool in Napu and Lindu valleys.(Zhou et al., 2008)

To increase community participation and community awareness among the local community in schistosomiasis control at the village level, a Schistosomiasis Control Team (Peda' Team) was formed. The formation of the Peda' team was inspired and modification from the Lawa Project in Thailand. The project's primary challenge has been learning how to build an effective disease prevention and control programme from the "bottom-up", including creating an understanding of liver fluke infection disease risk with the community (Sripa et al., 2015).

The team was formed to carry out schistosomiasis control activities and mobilize the community in such activities at the village level. It is included in the contents of village regulations on schistosomiasis control. The name Peda' comes from the Bada language that means litter-eating snail at the base. It would show that the Peda' team works to control schistosomiasis at the lower level or directly in the community.

\section{Material and Method}

The research has received proper permission from the Health Research and Development Agency Ethics Commission with number LB.02.01/2/KE.012/2019. The research was conducted in Lore Barat District, Poso 
Regency, from June until November 2019, as implementation research with a mixed methods research design (utilized quantitative and qualitative methods).

In a first step, a Schistosomiasis Control Team (Peda' Team) was formed. In the second step, they were trained about schistosomiasis control by Poso District Health Office. The third step, after the training, a community health education program was developed by the Peda' team, that includes an animated book, leaflet, and video about schistosomiasis control to promote improved community participation in schistosomiasis control for the entire community. While the Peda' Team conducted their roles in schistosomiasis control in the community, they were also assisted by the researcher team. And the last, they were also monitored and evaluated to improve their duty in the community.

\section{Peda'Team Formation}

The Peda' team was included in the village regulation on controlling schistosomiasis. The name Peda' was derived from the Bada local language that means litter-eating snail at the base. It would represent that the Peda' team will work to control schistosomiasis at the lower level or directly in the community. It consists of cadres in each village in Lore Barat. The number of team members is adjusted to the needs of each village. In 2019, there were five Peda' teams from Tuare, Kageroa, and Lengkeka Villages. There were four members of the team in Tomehipi Village and three in Kolori and Lelio Villages. The team structure consists of one chairman, one secretary, and members. In carrying out its duties, the team is responsible to the village head.

\section{Training for Peda' Team}

The Peda' team formed needs training to increase its members' knowledge and skills in controlling schistosomiasis. Therefore, training activities for the Schistosomiasis Control Team at the village level were held on 22-25 July 2019, in the form of classroom theory and practice both at the Lengkeka Schistosomiasis Laboratory and in the field to provide the team skills in carrying out their duties. The resource persons for the training came from the Poso District Health Office, the Donggala Research and Development Center, and the Lengkeka Schistosomiasis Laboratory.

The team also got the description of the tasks and procedures or how to carry out each task given. After the training was carried out, each village team planned a schedule of activities in carrying out their duties every month.

\section{Peda' Team's task implementation}

The team carried out tasks according to the schedule being implemented. The results were written in the workbook of each team, and reports were made every month. The implementation of the team's duties was accompanied by a Schistosomiasis Laboratory officer who had been appointed and given training in the context of being a mentor.

\section{Peda' Team Mentoring}

Mentoring was carried out in community-based snail surveillance activities (the team from Kolori and Lelio Villages had never conducted any snail survey activity, so they asked to be assisted in this activity), cleaning activities in focus areas (Gema Beraksi), spraying focus areas, surveying rats, and assistance in the preparation of the reports. Mentoring was provided by the Donggala Research and Development Center and the Lengkeka Schistosomiasis Laboratory. In the future, it was hoped that the implementation of the Bada model could continue even though research activities have ended. 


\section{Peda' Team Evaluation}

Evaluation activities were carried out through coordination meetings with Tripika Lore Barat, all village heads in Lore Barat, and the Peda' teams from all villages to find out the progress and evaluation of the implementation of the Peda' teams' tasks.

Measurement of implementation success

Success was measured by assessing three parameters, namely the coverage of stool collection, the schistosomiasis prevalence in human, and also the number of focus areas in the study site before and after the implementation. Those parameters were obtained from the Provincial Health Office that conducted the surveys.

\section{Results}

The implementation results in terms of the coverage of population stool collection can be seen in Table 1 .

Table 1. The Stool collection coverage in human in Lore Barat District

\begin{tabular}{llcc}
\hline No & Village & $\begin{array}{c}\text { Coverage of stool } \\
\text { collection in 2018 }(\%)\end{array}$ & $\begin{array}{c}\text { Coverage of stool } \\
\text { collection in 2019 }(\%)\end{array}$ \\
\hline 1 & Tuare & 78.57 & 85 \\
\hline 2 & Kageroa & 83.02 & 93.23 \\
\hline 3 & Tomehipi & 88.57 & 90.70 \\
\hline 4 & Lengkeka & 54.59 & 72.50 \\
\hline 5 & Kolori & 76.74 & 74.26 \\
\hline 6 & Lelio & 83.28 & 94 \\
\hline
\end{tabular}

The prevalence survey in humans has been carried out on residents aged two years and over in six villages in Lore Barat District. The coverage of stool collection in each village has, on average, reached the minimum target by the program, which was $80 \%$. Based on Table 1, it can be seen that the increase in coverage occurred in Tuare Village, increasing from $78.57 \%$ to $85 \%$, in Kageroa Village, from $83.02 \%$ to $93.23 \%$, in Tomehipi, from $88.57 \%$ to $90.7 \%$, and in Lelio, from $83.28 \%$ to $94 \%$. The highest increase occurred in Lengkeka Village, from $54.59 \%$ to $72.5 \%$.

The results of human stool examinations in Lore Barat in 2019 (Table 2) showed that there were no stool samples found positive for Schistosoma japonicum worm eggs. In 2018 it was $0.43 \%$ (eight people out of 1,846 examined) and in 2019 there were no human cases or $0 \%$.

Table 2. Schistosomiasis prevalence in human in Lore Barat District

\begin{tabular}{llcc}
\hline No & Village & Prevalence in $2018(\%)$ & Prevalence in 2019 $(\%)$ \\
\hline 1 & Tuare & 78,57 & 85 \\
\hline 2 & Kageroa & 83,02 & 93,23 \\
\hline 3 & Tomehipi & 88,57 & 90,70 \\
\hline 4 & Lengkeka & 54,59 & 72,50 \\
\hline 5 & Kolori & 76,74 & 74,26 \\
\hline 6 & Lelio & 83,28 & 94 \\
\hline
\end{tabular}


The number of focus areas of snails $O$. hupensis lindoensis in the Bada highlands, after intervention by the establishment of the Schistosomiasis Control Team, Gema Beraksi, and Environmental Engineering, has decreased (Figure 2).

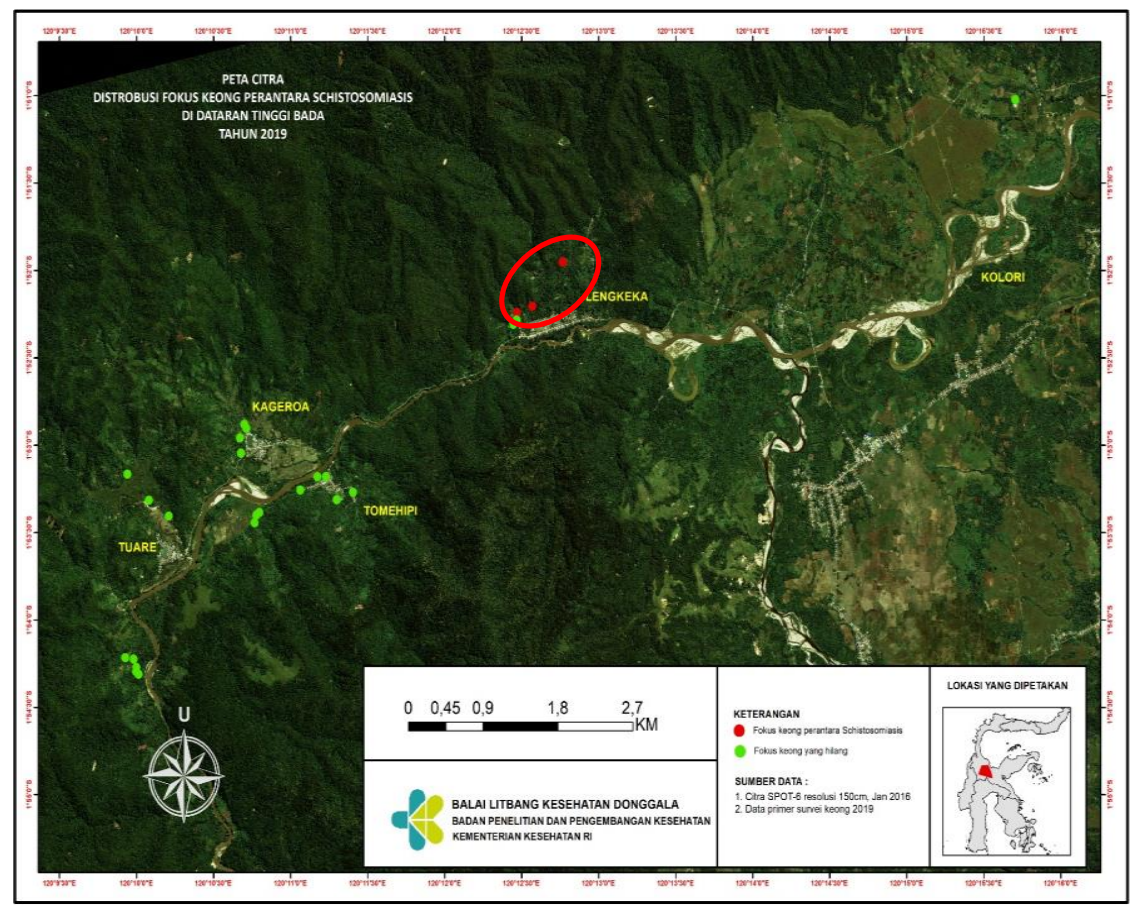

Figure 2. Snail foccus areas in Lore Barat District, 2019. (red spot: the area in which snails O.hupensis lindoensis were found, green spot: no more schistosomiasis intermediate snails were found)

\section{Discussion}

The implementation of the Bada model was an effort to empower the community in controlling schistosomiasis. Community participation was very much needed considering schistosomiasis transmission was very complicated. One of the successes of implementation research in disease control in other countries was the Lawa Model Project, which succeeded in reducing cases of Ophistorchiasis in Khon Khaen, Thailand. In that project, community empowerment was carried out in various fields, especially socialization efforts that covered all society levels, including school children, residents, and community leaders. The Lawa Model socialization efforts were carried out continuously and in various places that could reach the community, such as at schools, markets, and traditional events or community parties (Sripa et al., 2015; Tangkawattana \& Sripa, 2015)

One form of community empowerment in controlling schistosomiasis through the implementation of the Bada model was the formation of the Peda' team, which was a transformation of the schistosomiasis cadres that had previously been formed. The difference was that cadres had relatively limited tasks: only to help the community and laboratories to collect stools, while the Peda' team had relatively more tasks, including stool collection, mentoring the mobasa and mepaturo teams, conducting a population census, cleaning focus areas, surveying rats, assisting in spraying the focus areas of the snails, surveillance of snails to detect areas at which snails are suspected to live.

The formation of the Peda' team in order to support the prevention of schistosomiasis in the community, especially Lore Barat District, was running relatively well in accordance with the workload assigned to them. Based on the results of interviews with a number of informants who were members of the Peda' team and 
confirmed to the community, it was explained that the implementation of mentoring tasks carried out by the team to the mobasa (religious leaders) team and teachers who were also asked to be involved in the prevention of schistosomiasis disease (Mepaturo Team) went well.

The Peda's team also conducted socialization about schistosomiasis, both its causes, modes of transmission, examinations, ways of treatment, and prevention. The socialization delivered directly by community members who have been trained could be understood and followed by local residents. Community participation in controlling the disease would be better if they had appropriate knowledge about schistosomiasis. As in previous research conducted in the same location, learning about schistosomiasis in schoolchildren can increase the coverage of population stool collection (Erlan et al., 2020; Widayati et al., 2020).

Various studies have shown that disease control that directly involves the community has higher success, because the community is at the forefront of disease control, especially diseases originating from animals, such as schistosomiasis, dengue fever, and others (Ariyanti et al., 2020; Hestiningsih, 2019; Makaula et al., 2019; Pertiwi, 2019).

The collaborative work mechanism developed by the Peda' team in building awareness of the importance of overcoming schistosomiasis based on field observations was relatively effective. In addition to a collaborative mechanism, the Peda' team in several villages developed a "testimonial" mechanism during outreach, namely by directly asking community members who had been or were positively infected with schistosomiasis based on the results of their stool examination. They were asked to tell what experiences they felt when suffering from the disease.

The Peda' team played an important role in carrying out activities to eradicate focus areas with the community and was accompanied by Schistosomiasis Laboratory staff. The number of snail focus areas in Lore Barat decreased significantly after intensive eradication was carried out, by cleaning the focus area (Gema Beraksi) and followed by spraying the snails with molluscicide. The number of focus areas in Tuare Village and Tomehipi Village decreased to zero (0) from the previous eight focus areas, respectively. Kageroa Village decreased that from three to zero, and so did Lengkeka Village from five to three focus areas. Intensive cleaning and spraying activities have succeeded in eliminating schistosomiasis intermediate snails, thereby breaking the chain of schistosomiasis transmission.

A study in Kenya mentioned that religion and levels of income were significantly associated with participation in the research and control programme, history of ever suffering from schistosomiasis and intestinal worms were found to be significantly associated with participation in the research.(Macharia et al., 2016)

The study in Zimbabwe shows that community participation is a complex process upon which a multiplicity of social and cultural determinants have an impact. If community participation is to become successful in development programmes it ought to be viewed as a mutual learning process where obstacles are identified and discussed and solutions shared among community members and project staff. (Ndekha et al., 2003)

Schistosomiasis control in Indonesia has been implemented for more than 35 years. Other endemic countries' experience taught us that the disease could be eliminated only by integrating all sectors and community empowerment (Anastasia \& Widjaja, 2019; Macharia et al., 2016; Odhiambo et al., 2016; Widayati et al., 2020). The main challenge in schistosomiasis elimination is moving the sectors and the community's critical role at various levels. The Peda' team was one of the community approaches for schistosomiasis control at the bottom level (village level). They played an essential role in increasing community participation in the schistosomiasis control program. They also had advantages as being members of the local community and a better understanding of the local community's characteristics, habits, and language, so the socialization or suggestion that was delivered could be more understood and followed by the community. 


\section{Conclusion}

Based on the assessment of three parameters, the Peda' Team formation could support the schistosomiasis control program more effectively in the study site.

\section{Recommendation}

The formation of the Peda' team as one of the community approaches at the bottom level in schistosomiasis control should be implemented in other schistosomiasis endemic areas in Indonesia.

\section{Acknowledgment}

The authors would like to thank the Head of the Health Research and Development Center for full support and budgeting and to the Head and Leaders of Lore Barat District, the Head of the Lengkeka Community Health Center, the Head of the Lengkeka Schistosomiasis Laboratory, the Heads of the Six Villages in Lore Barat, the Peda' Team in Lore Barat, the entire research team, and field assistants who have helped this implementation research

\section{References}

Anastasia, H., \& Widjaja, J. (2019). Engaging multi-sectoral collaboration to combat schistosomiasis in Napu highlands, Poso District, Central Sulawesi. Journal of Physics: Conference Series, 1155(1). https://doi.org/10.1088/1742-6596/1155/1/012111

Ariyanti, R., Preharsini, I. A., \& Sipolio, B. W. (2020). Edukasi Kesehatan Dalam Upaya Pencegahan dan Pengendalian Penyakit Hipertensi Pada Lansia. To Maega: Jurnal Pengabdian Masyarakat, 3(2), 74. https://doi.org/10.35914/tomaega.v3i2.369

Dinas Kesehatan Provinsi Sulawesi Tengah. (2019). Laporan Schistosomiasis Sulawesi Tengah (2011-2019).

Erlan, Ahmad; Widjaja, Junus; Nur Widayati, Anis; Maksud, Malonda; Tolistiawaty, Intan; Murni; Mustafa, H. N. (2020). Implementasi Model Bada dalam Pengendalian Schistosomiasis di Desa Lengkeka, Kecamatan Lore Barat, Kabupaten Poso, Sulawesi Tengah. Buletin Penelitian Kesehatan, 48(3), 199-208. https://doi.org/https://doi.org/10.22435/bpk.v48i3.3246

Garjito, T. A., Sudomo, M., Abdullah, Dahlan, M., \& Nurwidayati, A. (2008). Schistosomiasis in Indonesia: Past and present. Parasitology International, 57(3), 277-280. https://doi.org/10.1016/j.parint.2008.04.008

Hestiningsih, R. (2019). Pemberdayaan Masyarakat Dalam Program Pencegahan dan Penanganan Penyakit Demam Berdaran Dengue ( DBD ) Berbasis Keluarga di Desa Lebak Kecamatan Grobogan Kabupaten Grobogan. Seminar Nasional Kolaborasi Pengabdian Kepada Masyarakat UNDIP-UNNES 2019, $242-244$.

Macharia, J. W., Ng'Ang'A, Z. W., \& Njenga, S. M. (2016). Factors influencing community participation in control and related operational research for urogenital schistosomiasis and soil-transmitted helminths in rural villages of Kwale county, coastal Kenya. Pan African Medical Journal, 24, 1-7. https://doi.org/10.11604/pamj.2016.24.136.7878

Makaula, P., Funsanani, M., Mamba, K. C., Musaya, J., \& Bloch, P. (2019). Strengthening primary health care at district-level in Malawi - Determining the coverage, costs and benefits of community-directed interventions. BMC Health Services Research, 19(1), 1-14. https://doi.org/10.1186/s12913-019-4341-5

Ndekha, A., Hansen, E. H., Mølgaard, P., Woelk, G., \& Furu, P. (2003). Community participation as an interactive learning process: Experiences from a schistosomiasis control project in Zimbabwe. Acta Tropica, 85(3), 325-338. https://doi.org/10.1016/S0001-706X(02)00256-5

Odhiambo, G. O., Musuva, R. M., Odiere, M. R., \& Mwinzi, P. N. (2016). Experiences and perspectives of community health workers from implementing treatment for schistosomiasis using the community directed intervention strategy in an informal settlement in Kisumu City, western Kenya. BMC Public Health, 16(1), 112. https://doi.org/10.1186/s12889-016-3662-0 
Pertiwi, K. D. (2019). Combat Dengue: Kegiatan Kreatif Berbasis Penguatan Masyarakat Dalam Upaya Penanggulangan Dbd Di Desa Gebugan. Jurnal Pemberdayaan Masyarakat Mandiri Indonesia (Indonesian Journal of Independent Community Empowerment), 2(3), 57-62. https://doi.org/10.35473/jpmmi.v2i3.33

Sripa, B., Tangkawattana, S., Laha, T., Kaewkes, S., Mallory, F. F., Smith, J. F., \& Wilcox, B. A. (2015). Toward integrated opisthorchiasis control in northeast Thailand: The Lawa project. Acta Tropica, 141(Part B), 361-367. https://doi.org/10.1016/j.actatropica.2014.07.017

Sudomo, M., \& dan Pretty, M. D. S. (2007). Schistosomiasis control in indonesia. Bul. Penelitian Kesehatan, $35(1)$.

Tangkawattana, S., \& Sripa, B. (2015). Lawa Model.

Widayati, Anis Nur; Rosmini, R., Mujiyanto, M., Koraag, M. E., Veridiana, N. N., Udin, Y., Chadijah, S., \& Tolistiawaty, I. (2020). Improving Schistosomiasis Knowledge Among School Children and Teachers in Central Sulawesi, Indonesia. In 5th Universitas Ahmad Dahlan Public Health Conference (UPHEC 2019) (Vol. 24, pp. 51-55). https://doi.org/10.2991/ahsr.k.200311.010

Zhou, X., Bergquist, R., Leonardo, L., \& Olveda, R. (2008). Schistosomiasis: The Disease and its Control. Tropical Medicine, (1). 